\title{
The Antibacterial Effect of Plant-Based Essential Oils
}

\section{*Marcos Flores-Encarnación ${ }^{1}$, Rosa María Nava-Nolazco ${ }^{1}$, Ricardo Carreño-López ${ }^{2}$, Germán Rubén Aguilar-Gutiérrez ${ }^{3}$, Silvia del Carmen García-García ${ }^{2}$, Carlos Cabrera-Maldonado ${ }^{4}$}

${ }^{1}$ Laboratorio de Microbiología Molecular y Celular. Edificio EM1-421. Biomedicina. Facultad de Medicina, Benemérita Universidad Autónoma de Puebla. Puebla. México.

${ }^{2}$ Centro de Investigaciones Microbiológicas. Instituto de Ciencias. Benemérita Universidad Autónoma de Puebla. Puebla. México.

${ }^{3}$ Centro de Investigación sobre Enfermedades Infecciosas. Instituto Nacional de Salud Pública. Cuernavaca, Morelos. México.

${ }^{4}$ Depto. de Microbiología. Facultad de Ciencias Químicas. Benemérita Universidad Autónoma de Puebla. Puebla. México.

\begin{abstract}
One of the advantages of using esential oils as an alternative therapeutic is that it has a wide range of antimicrobial activity. Essential oils of plants are composed of a mixture of aldehydes, alcohols, terpenoids and other compounds. Also currently the plant products have found wide application as alternatives to conventional therapy and food preservation. The essential oils are substances obtained from plant materials as flowers, leaves, fruits, branches, seeds, bark by different methods. The essential oils are secondary metabolites produced by plants in order to provide a defense function or attraction. Its range of action extends to both Gram negative as Gram positive bacteria and the antibacterial mechanisms are varied.
\end{abstract}

Keywords: Essential oil, antibacterial, plant, Gram negative, Gram positive.

\section{INTRODUCTION}

The medicinal plants have been used for therapeutic purposes since ancient times. The use of plants as traditional medicine in the treatment of various diseases dates from long before the discovery of the existence of microorganisms (Ali et al., 2015; Gutierrez et al., 2008; Patra and Baek, 2016). There are countless plant chemicals that can be considered drugs and are used in one or more countries, of which 74\% were discovered from use in traditional medicine (Ahmad, 1998; Ali et al., 2015). One of the advantages of using plants as an alternative therapeutic is that it has a wide range of antimicrobial activity because it contains a lot of active ingredients that make it toxic to microorganisms. Essential oils of plants are composed of a mixture of aldehydes, alcohols, terpenoids and other compounds (Diao et al., 2013). Currently the plant products have found wide application as alternatives to conventional therapy and food preservation (Carhuapoma et al., 2009; Castaño et al., 2010; Patra and Baek, 2016; Rincón-Mejía et al., 2012). Generally, essential oils of plants have been widely used for the treatment of various diseases which is why many medicinal plants have attracted scientific interest; they have antioxidant and anti-inflammatory properties (Patra and Baek, 2016; Sacchetti et al., 2005; Sokmen et al., 2004; Wu et al., 2009). Also it has been associated with modulation of various genetic pathways (Khoury et al., 2016).

In recent years there has been increasing interest in the use of biologically active organic compounds which are extracted from plant species that have the ability to eliminate pathogenic microorganisms by themselves; this is mainly due to the resistance that microorganisms have developed to antibiotics (Daferera et al., 2003; Marston et al., 2016).

\section{The Essential Oils as an Antimicrobial Alternative}

The aromatic essential oils are substances obtained from plant materials as flowers, leaves, fruits, branches, seeds, bark by different methods (Burt, 2004; Castañeda et al., 2007; Citarasu, 2010; Cowan, 1999; Sánchez et al., 2009). The essential oils are secondary metabolites produced by plants in order to provide a defense function or attraction (Butkiené et al., 2015). The defense mechanisms 
related to secondary metabolites include flavonoids, phenols, terpenes, oils, alkaloids, lectins and polypeptides (Solórzano-Santos and Miranda-Novales, 2012). Previously essential oils were used as flavorings or for cosmetic purposes (Ali et al., 2015). However, in recent years the discovery of its chemical components has aroused great interest because researchers have characterized some of them as potent antimicrobials and antioxidants (Burt, 2004; Sacchetti et al., 2005). In addition to the above, essential oils are characterized by a complex mixture of several compounds belonging to different classes of organic chemistry, for example: hydrocarbons, phenols, terpenes, alcohols, aldehydes, ketones, esters, ethers and others (Butkiené et al., 2015; Castañeda et al., 2007; Hassan et al., 2016; Kordali et al., 2005).

The essential oils have demonstrated insecticidal properties, antioxidant, antibacterial, antifungal and antiviral (Cowan, 1999; Gracia-Valenzuela et al., 2012; Kim and Park, 2013; Kordali et al., 2005; Sacchetti et al., 2005; Wojnicz et al., 2012). It has been shown that Lippia berlandieri (oregano), Thymus vulgaris (thyme) and Cinnamomum verum (cinnamon) have antioxidant properties related with phenolic compounds such as carvacrol and thymol and these can be used under certain conditions as fungicides and bactericides (Abdalá and Roozen, 2001; Burt, 2004; Cowan, 1999; Kordali et al., 2005). Some phenolic compounds derived from plant extracts have been reported as viable alternatives to antibiotics for the treatment of infectious agents in aquaculture (Citarasu, 2010).

\section{The Antibacterial ACtivity SPECTRUM}

It has been reported by several authors that aqueous and alcoholic extracts of leaves, stems and roots from Rhizophora mangle (red mangrove) have inhibitory effect on growth of Streptococcus pnemoniae, Staphylococcus aureus, Salmonella typhi, Escherichia. coli, Corynebacterium diphtheriae, Pseudomonas aeruginosa and Mycoplasma pneumoniae (Ferreira et al., 2011). Erkana et al., (2012) demonstrated the antibacterial activity versus Gram-negative bacteria of a group of terpenoids extracted from leaves of Murraya koenigii (curry). Prabuseenivasan et al., (2006) reported that 19 essential oils showed antibacterial activity. They demostrated a significant inhibitory effect by cinnamon, clove, geranium, lemon, lime, orange and rosemary oils. Cinnamon oil showed the highest activity at low concentrations; aniseed, eucalyptus and camphor oils showed the lowest antibacterial activity against the tested bacteria both Gram-negative and Gram-positive: Klebsiella pneumoniae, Proteus vulgaris, Bacillus subtilis, E. coli, P. aeruginosa, and S. aureus. It has been reported also the potent inhibitory effect of essential oil of oregano, thyme and basil on the growth of $E$. coli and $P$. aeruginosa (Al-Bayati, 2008; Gracia-Valenzuela et al., 2012; Paredes-Aguilar et al., 2007). Fig. 1 shows the inhibitory effect on growth of $E$. coli using the essential oil of thyme. It is a clear proof of the bactericidal effect of essential oils. Gualtieri et al., (2008) evaluated the antimicrobial activity of the ethanolic extracts of leaves from Azadirachta indica (neem) on Gram-positive and Gram-negative bacteria, having a greater antimicrobial activity against Gram-positive bacteria.

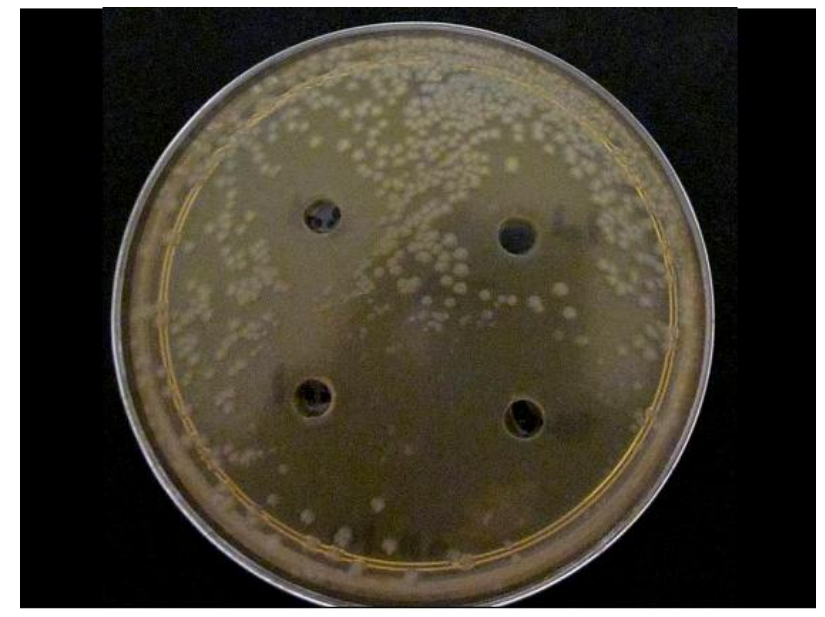

Fig1. The inhibitory effect of essential oil of thyme on E. coli growth. Diffusion test on agar with different concentrations of oil

On the other hand, it have been studied the antibiofilm activity in bacteria from plant products or extracts that are rich in bioactive compounds (Chmit et al., 2014). Naturally, bacteria are forming biofilms which are complex communities surrounded by a exopolymer matrix. Bacteria form colonies adherent to inert surfaces or human tissues and organs (Ceri et al., 1999; Donlan, 2011; Flores- 
Encarnación et al., 2014). It has reported that a biofilm consist of bacteria, water, exopolisacaride matrix, proteins, nucleic acids and bacterial lysis products (Decho, 2013). It has been reported that about $70 \%$ of human bacterial infections involve biofilms (Bjarnsholt, 2013; Potera, 1999). Biofilms have become the leading cause of infections related with medical devices, for example: vascular catheters, prosthetic joints and others (Donlan, 2011; Flores-Encarnación et al., 2014). Bacteria in biofilms can be up to 1000 -fold more resistant to antibiotic treatment than the same planktonic bacteria (Bjarnsholt, 2013; Flores-Encarnación et al., 2009).Wojnicz et al., (2012) showed that Betula pendula (birch) affected the expression of virulence factors and biofilm formation by uropathogenic E. coli. It inhibited between 43-80\% biofilm formation by E. coli, while Kim and Park (2013) showed that toluene extract from Zingiber officinalis (ginger) inhibited between $39-56 \%$ biofilm formation by $P$. aeruginosa PA14.

In all cases it has been observed that growth inhibition depends on the bacterial genus and concentration of essential oil probed. Por example: it has been reported that growth of Staphylococcus epidermidis and $S$. aureus (using the oil extracted from leaves and flowers from Acmella ciliata, misnamed weeds), it is inhibited by concentrations at $15-25 \mathrm{mg} / \mathrm{mL}$. Instead the oil from Lippia berlandieri (oregano) inhibited growth of Pseudomonas fluorescens, P. putida, Vibrio mimicus, V. alginolyticus at low concentrations of oil (50-100 $\mu \mathrm{g} / \mathrm{mL}$ ) (Gracia et al., 2012; Rincón et al., 2012). Something similar happens to growth of Helicobacter pylori which is inhibited by concentrations at 2 $\mu \mathrm{g} / \mathrm{mL}$ using the oil extracted from Minthostachys mollis (muña) (Carhuapoma et al., 2009).

\section{The Mode of Action of Essential Oils}

The essential oils have been used in various applications, for example: stimulating agents, diuretics and anti-rheumatic agents, some possessing insecticidal, antifungal and antibacterial activities against pathogenic microorganisms (Chmit et al., 2014). Because its effectiveness against a considerable number of pests, their low mammalian toxicity and general availability, they have been considered as active ingredients in some botanical pesticides (Mohan et al., 2011). Although the biological activity of essential oils has been confirmed by numerous studies, there has been a great variability among them; this it has been attributed to the composition of the oils. The different factors what influence in composition of essential oils have been reported, for example: physiological variations, environmental conditions, oil origin and method of production, storage conditions, climate of the geographical region, season year's, genetic factors and evolution. Also it has been reported that the maturity of the plant at the time of essential oil producing plays an important role in its composition (Figueiredo et al., 2008).

On the other hand, some mechanisms from antibacterial activity of essential oils have been determined. It has been reported that the antimicrobial activity depends mainly of chemical composition (hydrophilic or hydrophobic) of essential oil and microorganism that attack (Holley y Patel, 2005; Fisher y Phillips, 2008; Solórzano-Santos y Miranda-Novales, 2012). The hydrophilicity or hydrophobicity of the essential oil could be indicated whether it has the ability to alter and to penetrate the lipid membrane of bacteria, making it more permeable and causing leaking ions and cytoplasm and thus the lysis and death of bacteria (O'Bryan et al., 2015). In the cases mentioned above it has been observed the destabilization of bacterial cell membrane and wall, changes in bacterial membrane structure, alteration of the cell permeability, disturbance on respiration, modification of bacterial quorum sensing, potassium leakage from cells, effects on membrane potential (proton translocation), changes in $\mathrm{pH}$ gradient and ATP production of bacterial cell (O'Bryan et al., 2015). The terpene compounds are involved in the destabilization of the bacterial membrane (Rajendran et al., 2014). It has been postulated that the alkaloid compounds intercalate into double-stranded DNA, while lectins and polypeptides can form ion channels in the bacterial membrane or cause competitive exclusion by adhesion of bacterial proteins to host polysaccharides receptors (Cowan, 1999). Another reports indicate that the components of essential oils interfere with the functions of cell membrane permeability (Lambert et al., 2001). Jasmine et al., (2011) described the possible modes of action for terpenoids: 1 ). It increases membrane permeability to small ions; 2 ). It affects the structural stability of the membrane; 3). It destabilizes the packing of the lipid bilayer.

It has been described that some of the essential oils are more active against Gram-positive bacteria but other are more active against Gram-negative bacteria (Tiwari et al., 2015). Other authors have reported that Gram negative bacteria are more resistant to essential oils than Gram positive bacteria (Trombetta et al., 2005). As it is known Gram negative bacteria have an envelope consisting of 
lipopolysaccharides linked to outer membrane which restrict diffusion of hydrophobic molecules (Nazzaro et al., 2013). So Gram negative bacteria require greater concentrations of essential oils to inhibit their growth (Trombetta et al., 2005). Also it has been reported that the essential oils are equally effective in both bacteria. The difference is that to achieve the same lethal effect in Gram negative bacteria when bacteria are exposed more time to essential oil (Fisher y Phillips, 2008; Tajkarimi et al., 2010).

Considering the wide variety of chemical compounds that are part of the essential oils, the researchers propose that the antimicrobial activity is a synergism between the major components of the oil, so it could be more than one mechanism of action involved.

\section{CONClusion}

The antibacterial resistance is a serious problem distributed around the world that has been impacted on public health. For that reason it has revived the interest in essential oils and bioactive compounds as a possible alternative for the treatment and control of pathogenic bacteria and infectious diseases that cause them. In addition to the health area, essential oils are used in the food industry and agriculture as valuable biological pesticides, thanks to their antimicrobial properties.

\section{ACKNOWLEDGEMENTS}

Thanks to Daniela Amador-Bravo and Griselda Luna-Quizihuitl by Facultad de Medicina-BUAP for their invaluable technical assistance in the laboratory. Also thanks to PRODEP, VIEP-BUAP for the facilities provied for the development of this work.

\section{REFERENCES}

[1] Abdalá, A.E. and Roozen, J.P. (2011.). The effects of stabilized extracts of sage and oregano on the oxidation of salad dressings. Eur. Food Res. Technol. 212:551-560.

[2] Ahmad I., Mehmood Z. and Mohammad F. (1998). Screening of some Indian medicinal plants for their antimicrobial properties. J. Ethnopharmacol. 62:183-193.

[3] Al-Bayati F.A.(2008). Synergistic antibacterial activity between Thymus vulgaris and Pimpinella anisum essential oils and methanol extracts. J. Ethnopharmacol. 116:403-406.

[4] Ali B., Al-Wabel N.A. Shams S., Ahamad A., Khan S.A. and Anwar F. (2015). Essential oils used in aromatherapy: a systemic review. Asian Pac. J. Trop. Biomed. 5:601-611.

[5] Bjarnsholt T. (2013). The role of bacterial biofilms in chronic infections. APMIS. 121: 1 -51.

[6] Burt, S. (2004). Essential oils: their antibacterial properties and potential applications in foods-a review. Inter. J. Food Microbiol. 94:223-253.

[7] Butkiené R., Bidiené J., Judzentiene A. (2015). Variations of secundary metabolites (essential oils) in various plant organs of Juniperus communis L. wild growing in Lithuania. Baltic Forestry. 21:59-64.

[8] Carhuapoma M.Y., López S.G., Roque M.A., Velapatiño B., Bell C.C., Whu D.W. (2009). Actividad antibacteriana del aceite esencial de Minthostachys mollis Griseb "RUYAQ MUÑA". Ciencia e investigación. 12:83-89.

[9] Castañeda M.L., Muñoz M., Martínez J.R., Stashenko E. (2007). Estudio de la composición química y la actividad biológica de los aceites esenciales de diez plantas aromáticas colombianas. Scientia et Técnica. 13:165-166.

[10] Castaño H.I.P., Ciro G.G., Zapata J.E.M., Jiménez S.L.R. (2010). Actividad bactericida del extracto etanólico y del aceite esencial de hojas de Rosmarinus officinalis L. sobre algunas bacterias de interés alimentario. VITAE Rev. Fac. Quim. Farmac. 17:149-154.

[11] Ceri H., Olson M.E., Stemick C., Read R.R., Mork D. and Buret A. (1999). The Calgary biofilm device: new technology for rapid determination of antibiotic susceptibilities of bacterial biofilms. J. Clin. Microbiol., 37: 1771-1776.

[12] Chmit M., Kanaan H., Habib J., Abbass M., Mcheik A. and Chokr A. (2014). Antibacterial and antibiofilm activities of polysaccharides, essential oil, and fatty oil extracted from Laurus nobilis growing in Lebanon. Asian Pac. J. Trop. Med. 7:S546-S552.

[13] Citarasu, T. (2010). Herbal biomedicines: a new opportunity for aquaculture industry. Aquacult. Inter. 18:403-414. 
[14] Cowan, M.M. (1999). Plant products as antimicrobial agents. Clin. Microbiol. Rev. 12:564-565.

[15] Daferera, D.J., Ziogas, B.N. and Polissiou, M.G. (2003). The effectiveness of plant essential oils in the growth of Botrytis cinerea, Fusarium sp. and Clavibacter michiganensis subsp. michiganensis. Crop Protect. 22:39-44.

[16] Decho A.W. (2013). The EPS matrix as an adaptive bastion for biofilms: Introduction to special issue. Int. J. Mol. Sci. 14:23297-23300.

[17] Diao, W.R., Hu, Q.P., Feng, S.S., Li, W.Q. and Xu, J.G (2013). Chemical composition and antibacterial activity of the essential oil from green huajiao (Zanthoxylum schinifolium) against selected foodborne pathogens. J. Agric. Food Chem. 3:6044-6049.

[18] Donlan R.M. (2011). Biofilm elimination on intravascular catheters: important considerations for the infectious disease practitioner. Clin. Infect. Dis. 52:1038-1045.

[19] Erkana N., Tao Z., , Rupasinghea H.P.V., Uysalc B. and Oksalc B.S. (2012). Antibacterial activities of essential oils extracted from leaves of Murraya koenigii by solvent-free microwave extraction and hydro-distillation. Nat. Product Comm. 7:121-124.

[20] Ferreira F.S., Santos S.C., Barros T.F., Rossi-Alva J.C. and Fernandez L.G. (2011). Atividade antibacteriana in vitro de extratos de Rhizophora mangle L. Rev. Bras. Plantas Med. 13:305-310.

[21] Figueiredo A.C., Barroso J.G., Pedro L.G. and Scheffer J.J.C. (2008). Factors affecting secondary metabolite production in plants: volatile components and essential oils. Flavour Fragr. J. 23:213-226.

[22] Fisher, K. and Phillips, C. (2008). Potential antimicrobial uses of essential oils in food: is citrus the answer?. Trends in Food Sci. Technol. 19:156-164.

[23] Flores-Encarnación M., Aguilar-Gutérrez G.R., Ixtepan-Tejero C., Juárez-Salazar G., MartínezVaquero J.L., Cabrera-Maldonado, C. and Xicohténcatl-Palacios R.C. (2014). Biofilm: a natural mechanism of bacterial resistance. Inter. J. Curr. Res. 6:10420-10424.

[24] Flores-Encarnación M., Cortés-Maldonado L., Guzmán-Flores J.E., García-Nito F., MárquezRojas C.P. (2009). El papel de las biopelículas bacterianas en el mecanismo de resistencia a los antibióticos en infecciones crónicas. En: Lozano PZ, Rocha RCG, Martínez YL, editores. Antibióticos: uso, mecanismos de acción, de resistencia y antibioticoterapia. $1^{\mathrm{a}}$ Edición. México. Benemérita Universidad Autónoma de Puebla. p.271-285.

[25] Gracia-Valenzuela, M.H., Orozco-Medina C. and Molina-Maldonado C. (2012). Efecto antibacteriano del aceite esencial de orégano (Lippia berlandieri) en bacterias patógenas de camarón Litopenaeus vannamei. Hidrobiol. 22:201-206.

[26] Gualtieri M.J.A., González M.C., Contreras K.P.B., Noguera M.C.C., Uzcátegui E.E.M., Villasmil S. and Villalta C.R. (2008). Evaluación de la actividad antimicrobiana de los extractos etanólicos de Azadirachta indica. Rev. Inst. Nac. Hig. Rafael Rancel. 39:12-16.

[27] Gutierrez, J., Barry-Ryan, C. and Bourke, P. (2008). The antimicrobial efficacy of plant essential oil combinations and interactions with food ingredients. Inter. J. Food Microbiol. 124:91-97.

[28] Hassan W., Gul S., Rehman S., Noreen H., Shah Z., Mohammadzai I. and Zaman B. (2016). Chemical composition, essential oil characterization and antimicrobial activity of Carum copticum. Vitam. Miner. 5:2-5.

[29] Jasmine R., Selvakumar B.N. and Daisy P. (2011). Investigating the mechanism of action of terpenoids and the effect of interfering substances on an Indian medicinal plant extract demonstrating antibacterial activity. Inter. J. Pharmac. Studies and Res. 2:19-24.

[30] Holley, R. and Patel, D. (2005). Improvement in shelf-preparation techniques for the extraction and analysis of medicinal plants. Anal. Bioanal. Chem. 373:23-30.

[31] Khoury R.E., Atoui A., Verheecke C., Maroun R., Khoury A.E., and Mathieu F. (2016). Essential oils modulate gene expression and ochratoxin A production in Aspergillus carbonarius. Toxins. 8:1-14.

[32] Kim H.S. and Park H.D. (2013). Ginger extract inhibits biofilm formation by Pseudomonas aeruginosa PA14. PLoS One. 8:(9): e76106.

[33] Kordali, S., Kotan, R., Mavi, A., Cakir, A. Ala, A. and Yildirim, A. (2005). Determination of the chemical composition and antioxidant activity of the essential oil of Artemisia dracunculus and of the antifungal and antibacterial activities of turkish Artemisia absinthium, A. dracunculus, Artemisia santonicum, and Artemisia spicigera essential oils. J. Agric. Food Chem. 53:94529458. 
[34] Lambert, R.J., Skandamis, P.N., Coote P.J. and Nychas, G.J. (2001). A study of the minimum inhibitory concentration carvacol. J. Appl. Microbiol. 91:453-462.

[35] Marston H.D., Dixon D.M., Knisely J.M., Palmore T.N. and Fauci A.S. (2016). Antimicrobial resistance. JAMA. 316:1193-1204.

[36] Mohan M., Haider S.Z., Andola H.C. and Purohit V.K. (2011). Essential oils as green pesticides: for sustainable agriculture. RJPBCS. 2:100-106.

[37] Nazzaro F., Fratianni F., De Martino L., Coppola R. and De Feo V. (2013). Effect of essential oils on pathogenic bacteria. Pharmaceut. 6:1451-1474.

[38] O'Bryan C.A., Pendleton S.J., Crandall P.G. and Ricke S.C. (2015). Potential of plant essential oils and their components in animal agriculture- in vitro studies on antibacterial mode of action. Frontiers Vet. Sci. 2:1-8.

[39] Paredes-Aguilar, M.C., Gastélum-Franco, M,G., Silva-Vázquez, R. and Nevárez-Moorillón, G.V. (2007). Efecto antimicrobiano del oregano mexicano (Lipia Berlandieri Schauer) y de su aceite esencial sobre cinco especies del género Vibrio. Rev. Fitotec. Mex. 30: 261-267.

[40] Patra J.K. and Baek K.H. (2016). Antibacterial activity and action mechanism of the essential oil from Enteromorpha linza L. against foodborne pathogenic bacteria. Molecules. 21:1-11.

[41] Potera C. (1999). Forging a link between biofilms and disease. Science. 283:1837-1839.

[42] Prabuseenivasan S., Jayakumar M. and Ignacimuthu S. (2006). In vitro antibacterial activity of some plant essential oils. BMC Compl. Altern. Med. 6:39

[43] Rajendran M.P., Pallaiyan B.B., Selvaraj N., (2014). Chemical composition, antibacterial and antioxidant profile of essential oil from Murraya koenigii (L.) leaves. AJP. 4:200-214. 21

[44] Rincón-Mejía,C.A., Castaño-Osorio,J. Carlos, and Ríos-Vázquez, E. (2012). Actividad biológica de los aceites esenciales de Acmella ciliata (Kunth) Cass. Rev. Cub. Plantas Med. 17:160-171.

[45] Sacchetti, G., Maietti, S., Muzzoli, M., Scaglianti, M., Manfredini, S., Radice, M. and Bruni, R. (2005). Comparative evaluation of 11 essential oils of different origin as functional antioxidants, antiradicals and antimicrobials in foods. Food Chem. 91:621-632.

[46] SánchezY.,PinoO.,Correa T.M., Naranjo E., Ilgesia A. (2009). Estudio químico y microbiológico del aceite esencial de Piper auritum Kunth (caisimón de anís). Rev. Prot. Veg. 24:39-46.

[47] Sokmen, A., Gulluce, M., Akpulat, H.A., Daferera, D., Tepe, B., Polissiou, M., Sokmen, M. and Sahin, F. (2004). The in vitro antimicrobial and antioxidant activities of the essential oils and methanol extracts of endemic Thymus spathulifolius. Food Control. 15:627-634.

[48] Solórzano-Santos, F. y Miranda-Novales, M. (2012). Essential oils from aromatic herbs antimicrobial agents. Curr. Opinion Biotechnol. 23:136-141.

[49] Tajkarimi, M.M., Ibrahim, S.A. and Cliver, D.O. (2010). Antimicrobial herb and spice compounds in food. Food Control. 21:1199-1218.

[50] Tiwari V., Roy R. and Tiwari M. (2015). Antimicrobial active herbal compounds against Acinetobacter baumannii and other pathogens. Frontiers Microbiol. 6:1-11.

[51] Trombetta,D.,Castelli,F. Sarpietro,M.G., Venuti,V., Cristani, M., Daniele,C., Saija, A., Mazzanti, G.and Bisignano G.(2005). Mechanisms of antibacterial action of three monoterpenes. Antimicrob. Agents Chemother. 49:2474-2478.

[52] Wojnicz D., Kucharska A.Z., Sokól-Letowska A., Kicia M. and Tichaczek-Goska D. (2012). Medicinal plants extracts affect virulence factors expression and biofilm formation by the uropathogenic Escherichia coli. Urol Res. 40:683-697.

[53] Wu, V.C.H., Qiu, X., Delos-Reyes, B.G., Lin, C.S. and Pan, Y. (2009). Application of cranberry concentrate (Vaccinium macrocarpon) to control Escherichia coli O157:H7 in ground beef and its antimicrobial mechanism related to the down regulated slp, hdeA and cfa. Food Microbiol. 26:32-38. 